\title{
Hypoglycemic Efficacy of Catharanthus roseus and Opuntia ficusindica in Mice Diabetic Model
}

\author{
Shilpi Jaya and Baidyanath Kumar* \\ Department of Biotechnology, College of Commerce, Arts and Science Patna-800020, India \\ *Corresponding author
}

\begin{tabular}{|c|c|}
\hline & A B S T R A C T \\
\hline & Diabetes mellitus (DM) is a metabolic disorder of multiple etiologies \\
\hline Keywords & $\begin{array}{l}\text { characterized by absolute or relative deficiency of insulin secretion with or } \\
\text { without varying degree of insulin resistance. Sedentary life style and obesity are }\end{array}$ \\
\hline $\begin{array}{l}\text { Diabetes mellitus, } \\
\text { Catharanthus } \\
\text { roseus, Opuntia } \\
\text { ficusindica, } \\
\text { Streptozotocin, } \\
\text { Mice. }\end{array}$ & $\begin{array}{l}\text { two major epidemiological determinants of diabetes mellitus. In the present } \\
\text { investigation hypoglycemic efficacy of methanol extract of Catharanthus roseus } \\
\text { (Nayantara) of Apocyanaceae and Opuntia ficusindica of Cactaceae was tested on } \\
\text { STZ induced mice diabetic models. The results clearly indicated that the diabetic } \\
\text { control (DC) mice presented a significant lowering of body weight }(p<0.001)\end{array}$ \\
\hline Article Info & when compared with the normal control (NC) mice. The DC mice showed a \\
\hline $\begin{array}{l}\text { Accepted: } \\
\text { 17 June } 2017 \\
\text { Available Online: } \\
\text { 10 July } 2017\end{array}$ & $\begin{array}{l}\text { their normal control counterparts. Diabetic mice of both of the groups (DT } \mathrm{DT}_{150} \text { and } \\
\mathrm{DT}_{250} \text { ) showed a reduction in glucose levels, when compared to the DC ones. The } \\
\text { results clearly indicated that the methanol extract of } C \text {. roseus and } \text { O. ficusindica }\end{array}$ \\
\hline & $\begin{array}{l}\text { is antidiabetic in nature due to the presence of difterent types of active } \\
\text { phytochemicals. }\end{array}$ \\
\hline
\end{tabular}

\section{Introduction}

Diabetes mellitus (DM) is the third leading disease, after heart attack and cancer affecting almost every organ in the human body (Nyenwe et al., 2011) and is also called silent killer. This is a metabolic disorder of multiple etiologies (Mohler et al., 2009) characterized by absolute or relative deficiency of insulin secretion with or without varying degree of insulin resistance (Lin and Sun, 2010; Nyenwe et al., 2011).

Diabetes mellitus is characterized by recurrent or persistent hyperoglycemia with an elevated fasting $(>110 \mathrm{mg} / \mathrm{dL}$ of blood) and post prandial (> 130mg/dL of blood) plasma glucose level. According to WHO (2006) diagnosis a fasting plasma sugar of $>126 \mathrm{mg} / \mathrm{dL}$ and post prandial plasma sugar value of $>200 \mathrm{mg} / \mathrm{dL}$ is considered as diabetes mellitus. There are two major forms of diabetes mellitus namely Type-1, characterized by diminished production of insulin due to degeneration of pancreatic Bcells, and Type-2, the multifactorial syndrome characterized by either hypo secretion of insulin or insulin insensitivity or sometimes both. Sedentary life style and obesity are two major epidemiological determinants of 
diabetes mellitus. The current therapy of this disorder includes exogenous insulin administration (particularly in case of Type-1 diabetes mellitus), and oral hypoglycemic agents (for Type-2DM) which includes Metformin, Pioglitazone, Sulphonylurea etc. which may have adverse effects in diabetic subjects. Multiple risk factors for diabetes have been identified (WHO, 2006).

The greatest risk is impaired glucose tolerance, a precursor of diabetes. Thus, a number of type 2 diabetes prevention trials have included subjects with impaired glucose tolerance. These trials compared intensive lifestyle modifications (e.g., diet, exercise and weight loss), OHAs and placebo controls (Tuomilehto et al., 2001; Knowler et al., 2002). Ayurvedic treatment known as Apatarpana (balanced diet with restricted calories) and Santarpana (highly nutritious, high-calorie diet intended to increase weight) are recommended for patients with type 2 and type 1 diabetes, respectively (Sharma and Chandola, 2011).

Diabetes mellitus has been classified into some other specific types:

\section{Maturity- onset diabetes of the young (MODY)}

This subgroup is a relatively rare monogenic disorder characterized by non- insulindependent diabetes with autosomal dominant inheritance and an age at onset of 25 years or younger. Patients are nonobese, and their hyperglycemia is due to impaired glucoseinduced secretion of insulin.

\section{Diabetes due to mutant insulin}

This is a very rare subtype of nonobese Type2 diabetes. Since affected individuals were heterozygous and possessed one normal insulin gene, diabetes was mild, and showed autosomal dominant genetic transmission.

\section{Diabetes due to mutant insulin receptors}

In more than 40 people with diabetes, defects in one of their insulin receptor gene have been observed.

\section{Diabetes mellitus associated with a mutation of mitochondrial DNA}

Diabetes due to a mutation of mitochondrial DNA that impairs the transfer of leucine or lysine into mitochondrial proteins has been described. Most patients have a mild form of diabetes that responds to oral hypoglycemic agents. Two- thirds of patients with this subtype of diabetes have a hearing loss, and a smaller proportion had a syndrome of myopathy, encephalopathy, lactic acidosis, and stroke- like episodes (MELAS).

\section{Obese type- 2 patients}

The most common form of diabetes is secondary to extra pancreatic factors that produce insensitivity to endogenous insulin. When an associated defect of insulin production prevents adequate compensation for this insulin resistance, nonketotic mild diabetes occurs. The primary problem is a "target organ" disorder resulting in ineffective insulin action that can secondarily influence pancreatic B cell function.

\section{Chronic complications of diabetes}

Diabetes mellitus is associated with late clinical manifestations that include a number of pathologic changes that involve small and large blood vessels, cranial and peripheral nerves, and the lenses of eye. These lesions lead to hypertension, renal failure (nephropathy), blindness (retinopathy), autonomic and peripheral neuropathy, amputations of the lower extremities, myocardial infarction, and cerebrovascular accidents. 
The Clinical Practice Guidelines for the Prevention and Management of Diabetes recommends a target glycosylated hemoglobin $\left(\mathrm{HbA}_{1 \mathrm{c}}\right)$ concentration of $7.0 \%$ or less for all patients with diabetes and, for those in whom it can be safely achieved, a target $\mathrm{HbA}_{1 \mathrm{c}}$ concentration in the normal range, usually $\leq 6.0 \%$ (WHO, 2006). Although nonpharmacologic therapy (e.g., diet, exercise and weight loss) remains a critical component in the treatment of diabetes, pharmacologic therapy is often necessary to achieve optimal glycemic control. Orally administered antihyperglycemic agents (OHAs) can be used either alone or in combination with other OHAs or insulin. Various classes of OHAs are now available that target the different pathophysiologic factors contributing to diabetes: $\alpha$-glucosidase inhibitors to delay intestinal carbohydrate absorption (Lebovitz, 1997; Inzucchi, 2002; Bayraktar et al., 1996; Chiasson et al., 2002), biguanides to target hepatic insulin resistance (Bailey and Turner, 1996; Kirpichnikov et al., 2002; Zhou et al., 2001; Holmes et al., 1999; Salpeter et al., 2004), insulin secretagogues to increase pancreatic insulin secretion (Klepzig et al., 1999; Lebovitz, 2001; Strom et al., 2003; Hatorpe, 2002; McLeod, 2004), insulin sensitizers or thiazolidinediones which function as ligands for the peroxisome proliferator-activated receptor gamma (PPAR $\gamma)$ to target adipocyte and muscle insulin resistance (Lister et al., 1999; Finegood et al., 2001; Bell, 2003; Bakris et al., 2003; Herz et al., 2003; Nesto et al., 2003; Kelly et al., 1999; Lee et al., 2003), and intestinal lipase inhibitor or orlistat to inhibit fat absorption and promote weight loss in obese patients (Guerciolini, 1997; Hollander et al., 1998; Hanefeld and Sachse, 2002; Kelley et al., 2002).

Despite excellent potencies, these synthetic antidiabetic drugs had presented unwanted therapeutic profiles, marked by fluid retention, hypoglycemia at higher doses, liver problems, lactic acidosis, weight gain and potential cardiac hypertrophy. There is also evidence that hyperglycaemia per se has deleterious effects on beta cell function and insulin action (glucotoxicity). Thus, a concerted effort to search more effective drugs for T2DM has become the need of the time in terms of efficacy as well as safety due to the undesirable side effects of synthetic drugs.

Over the past 25 years, $50 \%$ of prescription drugs have been developed from natural products and their derivatives. These medicines have emerged as unique, safe, effective, and relatively inexpensive remedies producing minimal or no side effects with tall claims of efficacy as add on therapy (Heinrich et al., 2012). Herbal drugs with antidiabetic activity can be classified into four categories according to their mode of action the first group has insulinomimetic effect and includes plant like Momordica charantia (bitter gourd) (Grover and Yadav, 2004). Second group acts on the $\beta$-cells to increase the production of insulin and include plants like Allium cepa (onion) and Pterocarpus marsupium (Vijaysaar) (Grover and Vats, 2001). The third one enhances glucose utilization in diabetic patients and includes plants like Gingiber officinale (ginger), Cyamospsis tetragonalobus (Gower plant) and Grewia asiatica (phalsa). They increase the viscosity of gastrointestinal contents, slow gastric emptying and act as a barrier to diffusion (Grover and Vats, 2001). Fourth group act by miscellaneous mechanisms and include plants like Euphorbia prostrata, Fumaria parvia, Panax ginseng and Phyllanthus embelica. They may alter the fiber content and thereby altering the rate and speed of absorption of glucose from the gut (Grover and Vats, 2001). The isolation and formulation of active constituents from these plants along with their 
pharmacological and toxicological evaluation are the need of the modern therapeutics.

\section{Review of literature}

Type- 2 diabetes is the commonest form of diabetes constituting $90 \%$ of the diabetic population. The global prevalence of diabetes is estimated to increase to $5.4 \%$ by the year 2025 (King et al., 1998). The World Health Organization has predicted that the major burden will occur in the developing countries. The countries with the largest number of diabetic people are, and will be India, China and United States in 2025 (King et al., 1998). Epidemiological studies among migrant Asian Indians showed higher prevalence of Type- 2 diabetes compared with the host populations and other migrant ethnic groups (Zimmet, 1999).

Studies conducted in India have highlighted that not only is the prevalence of Type- 2 diabetes high, but also that it is increasing rapidly in the urban population (Mohan et al., 2001; Raman Kutty et al., 2000; Misra et al., 2001; Verma and Madhu, 2000; Iyer et al., 2000). The burden of Type- 2 diabetes and its complications related to Indian scenario has been illustrated by Ramachandran et al., 2002.

The genetics of Type- 2 diabetes has been reviewed by Torben Hansen, 2002. BeckNielson and Groop (1994) have suggested that the diabetic phenotype is the result of interaction of both genetic component and an important non- genetic component.

The coexistence of obesity, glucose intolerance, dyslipidemia, and hypertension, is termed as insulin resistance syndrome (IRS). Gerald Reaven (1988) initially proposed that resistance to insulin- mediated glucose disposal is the pathophysiological interface for several complex metabolic alterations and disease. Insulin resistance syndrome in Asian Indians has been reviewed by Misra and Bikram (2002).

Regarding chromosomal abnormalities deletion syndrome due to chromosome 22 q11.2 has been investigated by Elder et al., 2001 .

Transient neonatal diabetes mellitus (TNDM) is a rare condition which presents with intrauterine growth retardation, dehydration, and failure to thrive. The condition spontaneously resolves before 1 year of age but predisposes patients to Type- 2 diabetes later in life. Rebecca J Gardner et al., (1999) have previously shown that, in some cases, TNDM is associated with paternal uniparental disomy (UPD) of chromosome 6 and suggested that an imprinted gene responsible for TNDM lies within a region of chromosome 6q. By analyzing three families, two with duplications (family A and patient C) and one with several affected subjects with normal karyotypes (family B), Elder et al., (2001) have further defined the TNDM critical region. In patient $\mathrm{A}$, polymorphic microsatellite repeat analysis identified a duplicated region of chromosome 6 , flanked by markers D6S472 and D6S311. This region was identified on the Sanger Centre's chromosome 6 radiation hybrid map (http://www.sanger.ac.uk/HGP/Chr6) and spanned approximately $60 \mathrm{cR} 3000$.

Using markers within the region, 418 unique P1 derived artificial chromosomes (PACs) have been isolated and used to localize the distal breakpoints of the two duplications. Linkage analysis of the familial case with a normal karyotype identified a recombination within the critical region. This recombination has been identified on the radiation hybrid map and defines the proximal end of the region of interest. They therefore propose that an imprinted gene for TNDM lies within an 
18.72 cR3000 ( $5.4 \mathrm{Mb})$ interval on chromosome 6q24.1-q24.3 between markers D6S1699 and D6S1010.

Bakalov et al., (2009) have investigated that Turner syndrome (TS) is caused by the absence or fragmentation of the second sex chromosome, which is associated with increased risk of diabetes mellitus (DM), but the specific phenotype and genetic etiology of this trait are unknown. Cytogenetic factors related with diabetes have been largely reviewed by Bakalov et al., (2004), Salgin et al., (2006), Song et al., (2008), Neve et al., (2005), Snee et al., (2006), Zhao et al., (2005), Mokhtari et al., (2008) etc. Suheir Assady (2009) has suggested the stem cell based therapy of diabetes mellitus.

Despite excellent potencies, these synthetic antidiabetic drugs had presented unwanted therapeutic profiles, marked by fluid retention, hypoglycemia at higher doses, liver problems, lactic acidosis, weight gain and potential cardiac hypertrophy. There is also evidence that hyperglycaemia per se has deleterious effects on beta cell function and insulin action (glucotoxicity). Thus, a concerted effort to search more effective drugs for T2DM has become the need of the time in terms of efficacy as well as safety due to the undesirable side effects of synthetic drugs.

Pallab Das Gupta and Amartya De (2012) have compiled some herbal plants and their active ingredients which play an important role in the management of diabetes mellitus. The antidiabetic properties of Bitter melon (Momordica chantrantia), Fiery costus (Costus igneus), Dendelium (Taraxacum officinale), French Lilac (Golega officinalis), Termeric (Cutcuma longa), Bael (Aegle marmelus), Amla (Emblica officinalis), Fenugreek (Trigonella foenum- gracum), Ginseng (Panax ginseng), Nayantara
(Catharanthus roseus), Neem (Azadirachta indica), Cinnamon (Cinnamomum zeylanicum), black berry (Rubus fruticosus) etc. have been greatly illustrated (Shukla et al., 2000; Wadkar et al., 2008; Rakesh et al., 2009; Zhizun Song et al., 1997; Mostak Ahmad et al., 2009; Upendra Rao et al., 2010; KattiShanker et al., 2011; Kumar et al., 2012; Manisha Modak et al., 2007; Santwana Rani and Baidyanath Kumar, 2015).

Our knowledge regarding the management of diabetes mellitus by herbal products is insufficient. Therefore, it has been decided to study the active phytochemicals of some medicinal plants viz., Catharanthus roseus (Nayantara) of family Apocyanaceae, and Opuntia ficusindica of family Cactaceae in the management of Diabetes Mellitus in Mice Diabetic Model.

\section{Materials and Methods}

Methanol extract of Catharanthus roseus (Nayantara) and Opuntia ficusindica was used for assaying hypoglycemic activities in Streptozotocin induced mice diabetic models. These two plant species were collected from campus of College of Commerce, Patna and identified following relevant monographs of Indian Pharmacopoeia (2012). Freshly harvested plant materials (root, stem, leaves and flowers) were washed under running tap water, blotted with filter paper and was dried in the shade at room temperature.

The dried plant sample $(2.6 \mathrm{~kg})$ was then soaked with absolute methanol under reflux condition for the methanolic extract preparation. The sample was then homogenized with extraction buffer and the supernatant collected after three rounds of extraction. The solvent was evaporated under reduced pressure in a rotary evaporator at 40 ${ }^{0} \mathrm{C}$. To this thick paste colloidal silicon dioxide was added and dried in vacuum tube 
dryer. The obtained methanol extract was stored in deep freezer at $-20^{\circ} \mathrm{C}$ until further test.

Significant insights into the etiology of diabetes in human have been gained from the study of animal models. The albino mouse is an excellent model for study of human diabetes. Therefore all mice used in this study were in the albino genetic background. Adult albino mice weighing around 17-20 gram with $6.5 \pm 0.5 \mathrm{~cm}$ length are selected for experiments.

The mice were housed in shoe-box type cages under good hygienic conditions in the departmental animal house during experimental period. The mice were allowed to acclimatize for 15 days in an environmentally controlled room under standard environmental conditions $\left(21 \pm 2^{\circ} \mathrm{C}\right.$, $55 \pm 5 \%$ Relative humidity, $12 \mathrm{hr}$ Light: Dark cycle).

The mice were fed on diet consisted of wheat grains-1Kg, Choker wheat-250gm, Gram grains-250gm, Maize grains-250gm, Soybean grains-250gm, Sundrop oil-50gm, Milk powder-2 table spoon and Jaggery-50gm. This diet provided carbohydrate $48.3 \%$, crude protein $23.5 \%$, crude fat $5.9 \%$, crude ash $5.9 \%$ and crude fibre $3.9 \%(\mathrm{~W} / \mathrm{W})$.

In each cage one pellet of feed per mice was given. The diet was palatable to the animal as evidenced by feeding success. It has been observed that an adult mice normally intakes 4 to 5 gram of diet per day. The daily food consumption of the mice varied depending upon the physiological and health status of the mice as well as the environmental temperature. The consumption of food increased considerably when the mice were pregnant or at lactating stage and decreased considerably with the dose-duration and increased temperature in summer.
The animal model for the present study was based on multiple administration of low dose of freshly prepared streptozotocin (STZ). For induction of diabetes, initially the normal mice were kept 24 hours without food and water. The weight of normal mice was determined. Diabetes was induced by multiple intra-peritoneal injection of freshly prepared STZ solution in $0.05 \mathrm{M}$ sodium citrate $(\mathrm{pH}$ 4.5) at the dose of $35 \mathrm{mg} / \mathrm{kg}$ body weight followed by an hour of fasting. The mice were then allowed to access the respective food and water ad libitum. Mice with fasting blood glucose level of $200 \mathrm{mg} / \mathrm{dl}(7.8 \mathrm{mmol} / \mathrm{l})$ or higher were considered to be diabetic and were used in the study. A parallel set of control mice (non-diabetic) were injected with citrate buffer only.

The mice were grouped into five categories viz., Normal control (NC), Diabetic Control (DC), Diabetic Treated $\left(\mathrm{DT}_{150}\right)$, Diabetic Treated $\left(\mathrm{DT}_{250}\right)$ and Diabetic Treated $\left(\mathrm{DT}_{\mathrm{RZG}}\right)$. NC received only citrate buffer solution. DC group was STZ induced which received citrate buffer only. $\mathrm{DT}_{150}$ and $\mathrm{DT}_{250}$ received $150 \mathrm{mg} / \mathrm{Kg}$ and $250 \mathrm{mg} / \mathrm{Kg}$ body weight of methanol extract respectively. $\mathrm{DT}_{\mathrm{RGZ}}$ received rosiglitazone at a dose of $2 \mathrm{mg} / \mathrm{Kg}$ of body weight. All the mice were fed with common pellet diets for 2 weeks after arrival, and then randomly divided into two groups. One group continued to receive common pellet diets and constituted the normal group; the other was fed with diets high in fat and fructose, in order to induce type- 2 diabetes. All the mice had free access to food and water.

For the experiment, the mice were divided into five groups having six mice in each group: DC group (diabetic control mice), NC group (non-diabetic control mice) and three DT group (diabetic mice treated with two different doses of extract as well as rosiglitazone/ $\mathrm{kg}$ body weight). Body weights were recorded weekly during the 
experimental period. Treatment with extracts was started after one week of STZ treatment, which was considered as the $1^{\text {st }}$ day of treatment. Blood samples were taken after 8 hrs fasting from the retro-orbital sinus vein prior to the administration of test substances or the buffer and 4 weeks after the treatment under mild ether anesthesia and allowed to clot for 30 minutes at room temperature. Blood samples were centrifuged at $3000 \mathrm{rpm}$ for 20 minutes. Serum was separated and stored at $-20^{\circ} \mathrm{C}$ until biochemical estimations were carried out.

Data were statically analyzed by mean \pm S.E and by one-way ANOVA.

The results related to body weight change and blood glucose level in $\mathrm{mmol} / \mathrm{l}$ in mice during present course of investigation have been presented in tables 1-4 and figures 1-4.

\section{Results and Discussion}

The whole plant extract of Catharanthus roseus and Opuntia ficusindica has been reported to be effective in alleviating diabetes mellitus through its antioxidant and insulinpotentiating activities (Okoli et al., 2010). In the present investigation the effect of methanol extract of Catharanthus roseus and Opuntia ficusindica on body weight of mice was studied.

The results clearly indicated that the diabetic control (DC) mice presented a significant lowering of body weight $(p<0.001)$ when compared with the normal control (NC) mice (Table 1 and 2; Figs. 1 and 2). A significant gain in body weight was observed in the treated groups of diabetic mice (DT 150 and $\mathrm{DT}_{250}$ ) as compared to the DC ones. The $\mathrm{DT}_{150}$ and $\mathrm{DT}_{250}$ group showed an increase of $30 \%$ and $40 \%$ in body weight respectively after 15 days of treatment. Contrary to this, $\mathrm{DT}_{\mathrm{RGZ}}$ group mice showed an increase of
$50 \%$ in body weight after 15 days of treatment (Table 1 and 2; Figs. 1 and 2).

The changes in the blood glucose levels before and after receiving the treatment in normal and diabetic mice have been presented in tables 3 and 4 and figures 3 and 4. As expected, the DC mice showed a significantly $(p<0.001)$ higher level of glucose $(+279 \%)$, when compared with their normal control counterparts. Diabetic mice of both of the groups ( $\mathrm{DT}_{150}$ and $\mathrm{DT}_{250}$ ) showed a reduction in glucose levels, when compared to the DC ones; nevertheless, the reduction was particularly evident in the $\mathrm{DT}_{250}$ mice $(-44 \%$; $p<0.001)$. When compared, the glucose levels of the $\mathrm{DT}_{250}$ versus the DC group mice during the 4-week treatment program, a significant lower value in the first was also found $(-45 \% ; p<0.001)$ respectively (Tables 2 and 4; Figs 3 and 4). Nevertheless, this decline in the glucose levels was less evident in the $\mathrm{DT}_{150}$ mice $(-38 \%)$ than in the $\mathrm{DT}_{250}$ mice. In contrast to this, $\mathrm{DT}_{\mathrm{RGZ}}$ group mice showed almost $70 \%$ decline in glucose level after 4weeks of treatment program (Tables 3 and 4; Figs. 3 and 4).

Phytochemicals from natural products possess potent antioxidant activity that are capable of prevention of the onset and/or progression of many human diseases by counteracting reactive oxygen species (ROS) (Palasuwan et al., 2005; Cai et al., 2006; Bouayed et al., 2007; Liu et al., 2007). It has been reported that the Catharanthus roseus possesses anticancer alkaloids Vinblastine and Vincristine, anti-diabetic property, antioxidant property, Anti helminthic property, Anti-ulcer property, Hypertensive property and Anti-diarrheal property (Monika Sain and Vandana Sharma, 2013). Similarly, phytochemicals of Opuntia ficus- indica equally possesses potent hypoglycemic activity (Hanane Dib et al., 2013). 
An alcoholic extract of both Catharanthus roseus and Opuntia ficus- indica was found to reduce significantly the blood sugar in normal mice and in STZ induced diabetes mice. In normal rats, administration of $C$. roseus and $O$. ficus- indica separately at the rate of $200 \mathrm{mg} / \mathrm{kg}$ body weight reduced the blood sugar by 35.5 percent and to 48.5 percent at the concentration of $1000 \mathrm{mg} / \mathrm{kg}$ by weight at 1 hour. However at 6th hour, values are almost similar to normal value. Continuous administration of the drug produced significant reduction in normal blood sugar in rats, which on 15th day was also found to reduce the blood sugar in alloxan diabetic rats. In short term experiment, drug was found to reduce the blood sugar at 4th hour by 6.07 percent at dose level of $200 \mathrm{mg} / \mathrm{kg}$ by weight and 18.7 percent at concentration of $1000 \mathrm{mg} / \mathrm{kg}$ by weight. Continuous administration of drug produced significant reduction in blood sugar in alloxan diabetic rats. On $15^{\text {th }}$ day values were almost similar to normal in the group taking $1000 \mathrm{mg} / \mathrm{kg}$ by weight. Plant extract did not produce any toxicity as seen from liver and kidney function test and in hematological parameters.
The results indicated potential antidiabetic action of $C$. roseus and $O$. ficus- indica.

Diabetes has a significant impact on the health, quality of life and life expectancy of patients as well as healthcare expenditure. With increasing incidence and mortality from its complications, prompt and adequate glycemic control in diabetes is paramount if management can meaningfully improve the quality of life and increase life expectancy (Nyenwe et al., 2011).

Several studies to test new drugs with potential antidiabetic activity were used in animal models of streptozotocin (STZ)induced diabetes (Fröde and Madeiros, 2008). Although none of the chemically-induced diabetic models can reproduce the complexity of the human disease, they can be helpful to understand at least some aspects of the potential bioactivities of natural or synthetic products. We used diabetic albino mice induced by STZ (35 mg/kg body wt.), which was sufficient to induce a stable state of diabetic condition in this animal species.

Table.1 Showing body weight changes in mice during and after treatment of methanol extract of Catharanthus roseus

\begin{tabular}{|c|c|c|c|}
\hline \multirow{2}{*}{ Non Diabetic Normal Control (NC) } & Day 0 & Day7 & Day15 \\
\hline & $19.50 \pm 2.76$ & $21.75 \pm 2.39$ & $24.85 \pm 2.20$ \\
\hline \multicolumn{4}{|l|}{ Diabetic Mice } \\
\hline Diabetic Control (DC) & $11.70 \pm 1.05$ & $09.75 \pm 0.95$ & $8.55 \pm 1.32$ \\
\hline C. roseus extract $(150 \mathrm{mg} / \mathrm{Kg})\left(\mathrm{DT}_{150}\right)$ & $11.71 \pm 2.03 *$ & $12.12 \pm 1.67 *$ & $13.75 \pm 1.53 *$ \\
\hline C. roseus extract $(250 \mathrm{mg} / \mathrm{Kg})\left(\mathrm{DT}_{250}\right)$ & $11.68 \pm 1.63 *$ & $12.75 \pm 2.37 *$ & $15.85 \pm 2.67 *$ \\
\hline Rosiglitazone (2mg/Kg) (DT $\left.{ }_{\mathrm{RGZ}}\right)$ & $11.70 \pm 3.74 *$ & $15.85 \pm 3.91 *$ & $16.25 \pm 1.84 *$ \\
\hline
\end{tabular}

*significant as compared to control; $\mathrm{n}=6$ in each group

Table.2 Showing body weight changes in mice during and after treatment of methanol extract of Opuntia ficusindica

\begin{tabular}{|c|c|c|c|}
\hline \multirow{2}{*}{ Non Diabetic Normal Control (NC) } & Day 0 & Day7 & Day15 \\
\hline & $19.50 \pm 2.76$ & $21.75 \pm 2.39$ & $24.85 \pm 2.20$ \\
\hline \multicolumn{4}{|l|}{ Diabetic Mice } \\
\hline Diabetic Control (DC) & $11.75 \pm 1.05$ & $10.25 \pm 0.95$ & $9.57 \pm 1.32$ \\
\hline O.ficusindica extract $(150 \mathrm{mg} / \mathrm{Kg})\left(\mathrm{DT}_{150}\right)$ & $11.80 \pm 2.03 *$ & $12.25 \pm 1.67 *$ & $14.25 \pm 1.53 *$ \\
\hline O. ficusindica extract $(250 \mathrm{mg} / \mathrm{Kg})\left(\mathrm{DT}_{250}\right)$ & $11.70 \pm 1.63^{*}$ & $12.75 \pm 2.37 *$ & $15.85 \pm 2.67 *$ \\
\hline Rosiglitazone $(2 \mathrm{mg} / \mathrm{Kg})\left(\mathrm{DT}_{\mathrm{RGZ}}\right)$ & $10.75 \pm 3.74 *$ & $15.85 \pm 3.91 *$ & $17.05 \pm 1.84 *$ \\
\hline
\end{tabular}


Table.3 Showing effects of different doses of $C$. roseus extract and Rosiglitazone on blood glucose levels in mice

\begin{tabular}{|c|c|c|c|c|c|}
\hline \multirow[t]{3}{*}{ Mice Groups } & \multicolumn{5}{|c|}{ Blood glucose levels in $(\mathrm{mmol} / \mathrm{l})$ in four different weeks } \\
\hline & \multirow{2}{*}{$\begin{array}{c}\text { Pretreatment } \\
0\end{array}$} & \multicolumn{4}{|c|}{ Post-treatment } \\
\hline & & 1 & 2 & 3 & 4 \\
\hline $\begin{array}{l}\text { Normal } \\
\text { control (NC) }\end{array}$ & $4.25 \pm 0.13 * *$ & $4.35 \pm 0.14 * *$ & $4.30 \pm 0.25 * *$ & $4.32 \pm 0.16 * *$ & $4.25 \pm 0.19 * *$ \\
\hline $\begin{array}{l}\text { Diabetic } \\
\text { control (DC) }\end{array}$ & $14.75 \pm 1.55 *$ & $14.85 \pm 1.48 *$ & $14.78 \pm 1.59 *$ & $14.95 \pm 1.49 *$ & $14.94 \pm 1.48 *$ \\
\hline $\begin{array}{l}\text { C. roseus } \\
\text { extract } \\
(150 \mathrm{mg} / \mathrm{Kg}) \\
\mathrm{DT}_{150}\end{array}$ & $14.97 \pm 1.40$ & $12.04 \pm 1.18 *$ & $10.64 \pm 2.09 * *$ & $9.69 \pm 1.28 * *$ & $9.27 \pm 1.79 * *$ \\
\hline $\begin{array}{l}\text { C. roseus } \\
\text { extract } \\
(250 \mathrm{mg} / \mathrm{Kg}) \\
\mathrm{DT}_{250}\end{array}$ & $14.64 \pm 1.59$ & $10.86 \pm 1.38 * *$ & $8.65 \pm 1.28 * *$ & $8.25 \pm 1.74 * *$ & $8.15 \pm 1.28 * *$ \\
\hline $\begin{array}{l}\text { Rosiglitazone } \\
\text { (2mg/Kg) } \\
\text { DT }_{\mathrm{RGZ}} \\
\end{array}$ & $15.03 \pm 1.49$ & $9.84 \pm 1.48 * *$ & $5.57 \pm 1.28 * *$ & $4.95 \pm 1.35 * *$ & $4.97 \pm 0.97 * *$ \\
\hline
\end{tabular}

$* \mathrm{p}<0.05$ as compared with normal control. **p $<0.001$ as compared with diabetic control.

Table.4 Showing effects of different doses of Opuntia ficusindica extract and Rosiglitazone on blood glucose levels in mice

\begin{tabular}{|c|c|c|c|c|c|}
\hline \multirow[t]{3}{*}{ Mice Groups } & \multicolumn{5}{|c|}{ Blood glucose levels in $(\mathrm{mmol} / \mathrm{l})$ in four different weeks } \\
\hline & \multirow{2}{*}{$\begin{array}{c}\text { Pretreatment } \\
0\end{array}$} & \multicolumn{4}{|c|}{ Post-treatment } \\
\hline & & $\mathbf{1}$ & 2 & 3 & 4 \\
\hline $\begin{array}{l}\text { Normal } \\
\text { control (NC) }\end{array}$ & $4.25 \pm 0.13 * *$ & $4.35 \pm 0.14 * *$ & $4.30 \pm 0.25 * *$ & $4.32 \pm 0.16 * *$ & $4.25 \pm 0.19 * *$ \\
\hline $\begin{array}{l}\text { Diabetic } \\
\text { control (DC) }\end{array}$ & $14.75 \pm 1.55 *$ & $14.85 \pm 1.48 *$ & $14.78 \pm 1.59 *$ & $14.95 \pm 1.49 *$ & $14.94 \pm 1.48 *$ \\
\hline $\begin{array}{l}\text { C. roseus } \\
\text { extract } \\
(150 \mathrm{mg} / \mathrm{Kg}) \\
\mathrm{DT}_{150}\end{array}$ & $14.93 \pm 1.40$ & $12.24 \pm 1.18 *$ & $11.64 \pm 2.09 * *$ & $9.65 \pm 1.28 * *$ & $9.25 \pm 1.79 * *$ \\
\hline $\begin{array}{l}\text { C. roseus } \\
\text { extract } \\
(250 \mathrm{mg} / \mathrm{Kg}) \\
\mathrm{DT}_{250}\end{array}$ & $14.75 \pm 1.59$ & $9.86 \pm 1.38 * *$ & $8.55 \pm 1.28 * *$ & $8.35 \pm 1.74 * *$ & $8.25 \pm 1.28 * *$ \\
\hline $\begin{array}{l}\text { Rosiglitazone } \\
(2 \mathrm{mg} / \mathrm{Kg}) \\
\mathrm{DT}_{\mathrm{RGZ}} \\
\end{array}$ & $15.03 \pm 1.49$ & $9.85 \pm 1.48 * *$ & $5.65 \pm 1.28 * *$ & $4.75 \pm 1.35 * *$ & $4.85 \pm 0.97 * *$ \\
\hline
\end{tabular}

$* \mathrm{p}<0.05$ as compared with normal control. **p $<0.001$ as compared with diabetic control. 
Fig.1 Body weight changes in mice during and after treatment of methanol extract of Catharanthus roseus

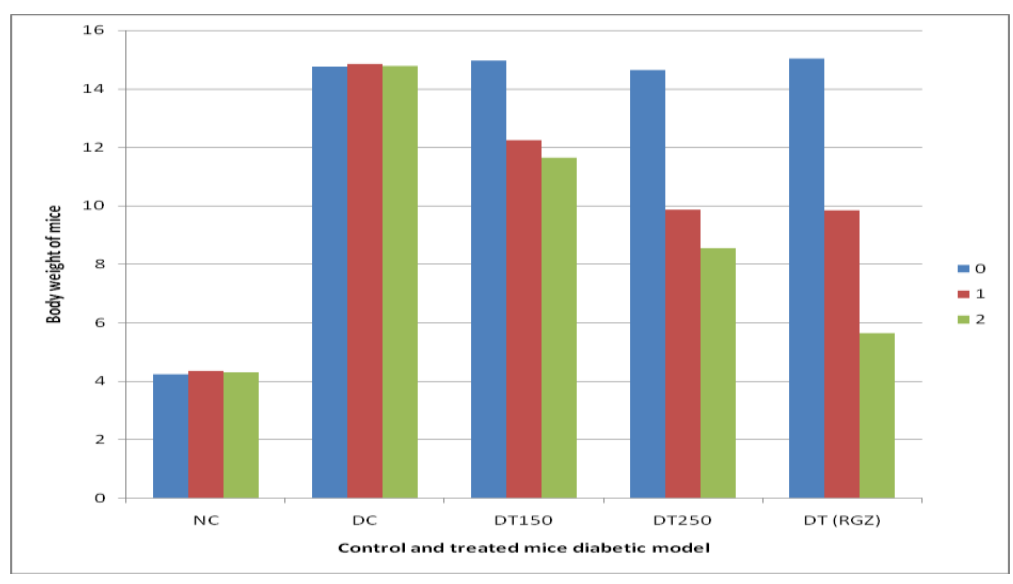

Fig.2 Body weight changes in mice during and after Treatment of methanol extract of Opuntia ficusindica

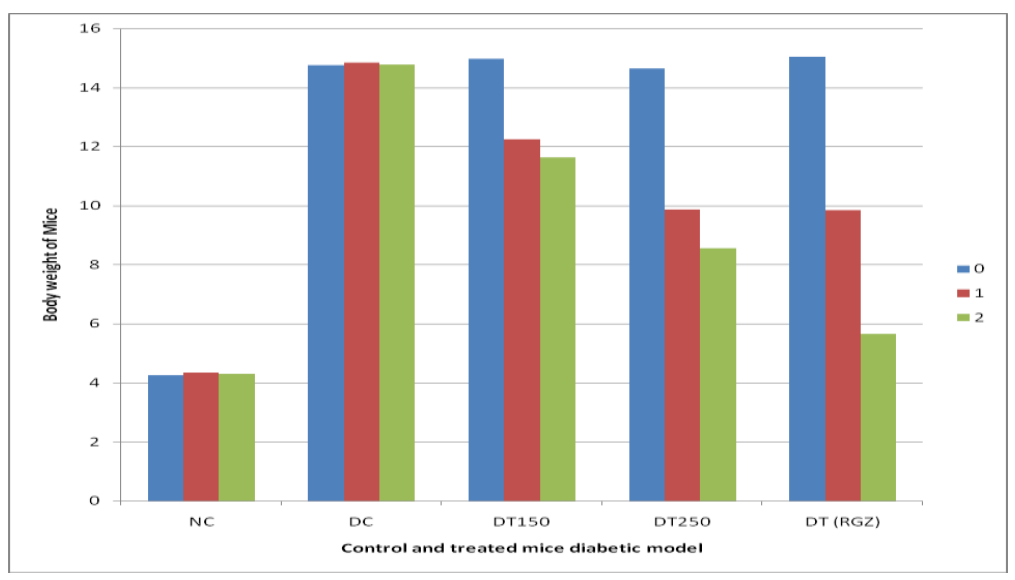

Fig.3 Effects of different doses of Catharanthus roseus extract and Rosiglitazone on blood glucose levels in mice

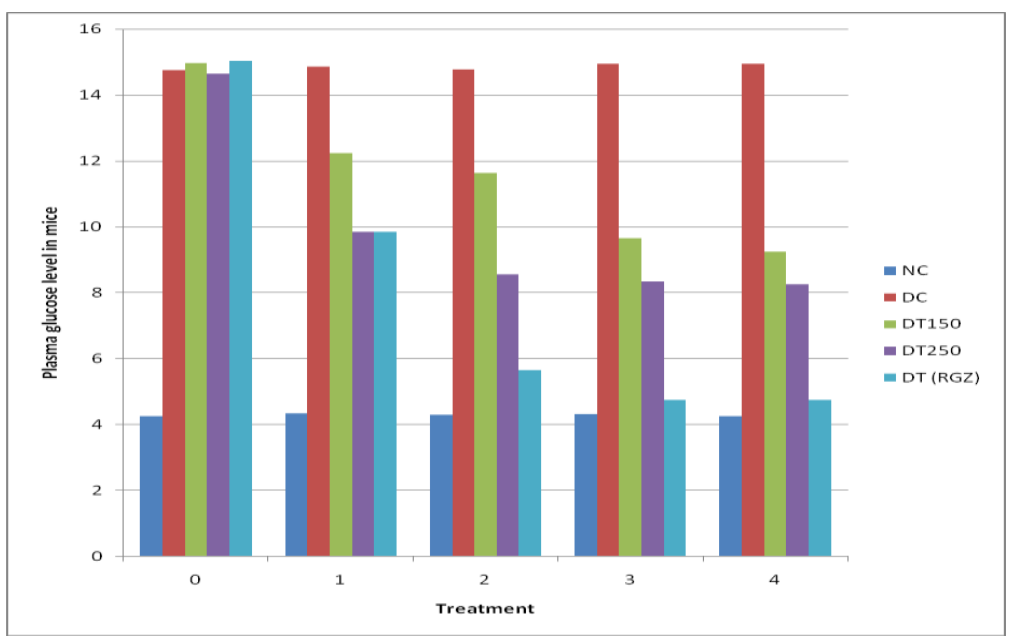


Fig.4 Effects of different doses of Opuntia ficusindica extract and Rosiglitazone on blood glucose levels in mice

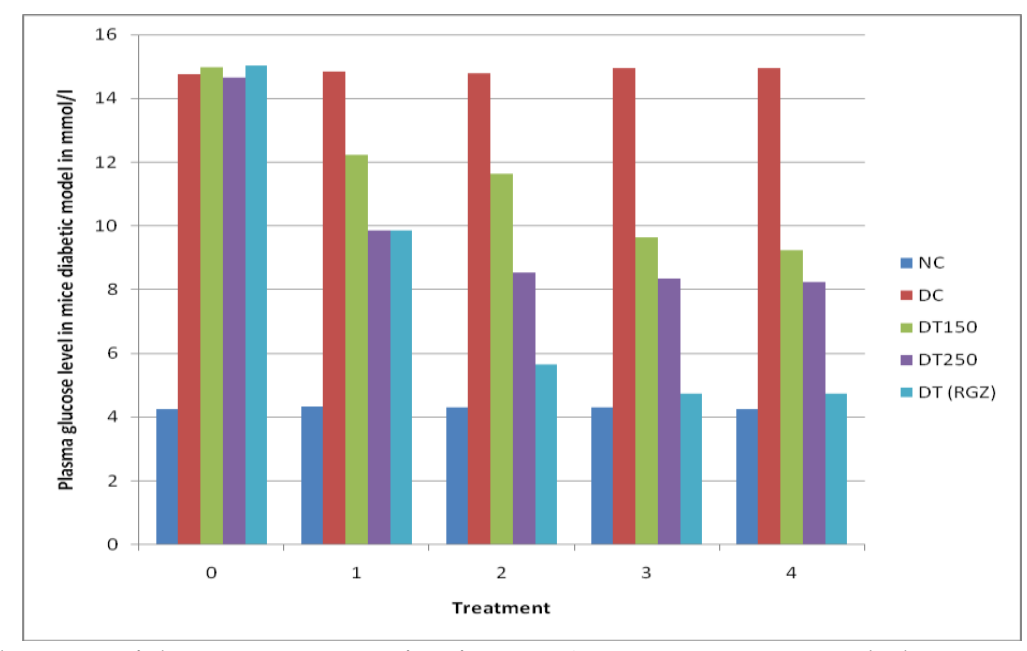

Induction of diabetes with streptozotocin is associated with a characteristic loss of body weight, which is probably due to muscle wasting. In our study there was a significant weight loss in the vehicle treated diabetic mice, whereas treatment with the $C$. roseus and $O$. ficus- indica extract at three doses showed improvement in their body weight, indicating that the methanolic extract had beneficial effect in preventing loss of body weight of diabetic mice. The probable mechanism of this benefit is due to its effect in controlling muscle wasting, i.e., by reversal of antagonism. The metabolic disturbances were corrected after the plant extract was administered at the two different dose of 150 and $250 \mathrm{mg} / \mathrm{kg}$ body weight for four weeks as shown by a reduction in biochemical parameters in diabetic mice treated with plant extract. This result is in accordance with Lenzen (2008) and Chung et al., (2003). They have found that multiple low dose of STZ sufficiently induce stabilized acute diabetes in which there is a progressive deterioration in the glucose tolerance and insulin secretion after the STZ injection. It ultimately causes increased oxidative stress, which play an important role in the pathogenesis of various complications.
At present, several drugs are available for the management of hyperglycemia but they are expensive and possess side effects also. Therefore, search for a suitable alternative is continued. For the developing countries herbal plants may be the most attractive target for their availability, low cost and better safety margin. The hypoglycemic activity of Catharanthus roseus and Opuntia ficusindica has attracted many researchers to prove it scientifically and to investigate its mechanisms of actions. Hence, in the present study, the two defined doses of methanolic extract of whole plant of $C$. roseus and $O$. ficus- indica have been investigated for their antidiabetic potential.

Chronic hyperglycaemia in diabetes is a risk factor constantly fuelled by postprandial elevation of blood glucose. Control of postprandial hyperglycemia in diabetes is of great importance due to its close relation to the risk of micro and macro-vascular complications and death (Nyenwe et al., 2011). In this study, experimental evaluation of the hypoglycemic potentials of $C$. roseus and O. ficus- indica has shown that the higher dose of extract ( $250 \mathrm{mg} / \mathrm{kg}$ body wt.) suppress postprandial rise in blood glucose levels more effectively than lower dose of extract (150 
$\mathrm{mg} / \mathrm{kg}$ body wt.) which is the index of effectual glycemic control. It may be due to alteration in the fiber content as well as phytochemical interactions which thereby altering the rate and speed of absorption of glucose from the gut. These favorable effects of $C$. roseus and O. ficus-indica extract may be attributed to higher affinity and synergistic action of their phytochemicals on multiple targets including PPAR- $\gamma$ activation and DPPIV inhibition which may therefore regulate the hyperglycemia, lipogenesis and hypertriglyceridemia associated with diabetes (Shimizu et al., 2003; Barnett, 2006).

The anti-oxidant and antidiabetic activity of C. roseus is due to the presence of its active phytoconstituents (Monika Sain and Vandana Sharma, 2013). It has been well documented that $C$. roseus contains vincristin, vinblastin and antidiabetic compounds as major active constituents (Monika Sain and Vandana Sharma, 2013).

In the hypoglycemic activity studies of methanol extract, daily oral administration of the extract for 28 days produced a gradual but sustained reduction in blood glucose levels in diabetic treated mice. Streptozotocin causes hyperglycaemia and glucose intolerance or syndromes similar to either type 1 or type 2 diabetes (Frode and Medeiros, 2008). Effective and sustained reduction in blood glucose levels of treated diabetic mice by the extract indicates that it may be useful in overt cases of diabetes. Treatment with the two doses of extract also reduced mortality of diabetic mice from hyperglycaemia and prolonged their survival. In this study, some of the diabetic non-treated control animals all died on day 10 post-induction of diabetes whereas the extract-treated group survived beyond the period of the experiment. Effective control of blood glucose level is a key step in preventing and reversing diabetic complications, and improving the quality of life of diabetic patients (Bavarva and Narasimhacharya, 2008). Hence, chronic administration of the extract may cause a progressively sustained reduction in hyperglycaemia known to reduce the risk of complications associated with the disease.

From the results it can be concluded that the methanol extract of whole plant of Catharanthus roseus and Opuntia ficusindica is antidiabetic in nature due to the presence of different types of active phytochemicals, which may have different mechanism of action. The combination of these phytochemicals, therefore, might be beneficial as hypoglycemic agents. The $C$. roseus and $O$. ficus- indica plant extract might be considered as a safe supplementary therapy for long- term and effective management of diabetic patients.

\section{Acknowledgement}

The first author is thankful to Dr. Baidyanath Kumar, Visiting Professor, Department of Biotechnology, College of Commerce (MU), Patna for providing necessary suggestion for the preparation of this research article.

\section{References}

Anoop Misra and Naval K. Vikram (2002): Insulin resistance sundrome (metabolic syndrome) and Asian Indians, CURRENT SCIENCE, 83 (12), 1483- 1496.

Ayurvedid Pharmacopoea (2001): Ministry of health and Family Welfere, Govt. of India.

Bagalkotkar G, Sagineedu SR, Saad MS, Stanslas J. Phytochemicals from Phyllanthus niruri Linn. And their pharmacological properties: a review. J Pharm Pharmacol. 2006; 58: $1559 \mathrm{e} 1570$.

Bailey CJ, Turner RC. Metformin. N Engl J Med 1996; 334: 574-9.

Bakris G, Viberti G, Weston WM, Heise M, Porter LE, Freed MI. Rosiglitazone reduces urinary albumin excretion in type II diabetes. J Hum Hypertens 2003; 17(1):7- 
12.

Balamurugan AN, Miyamoto M, Wang W, Inoue K, Tabata Y(2003): Streptozotocin (STZ) used to induce diabetes in animal models. $J$ Ethnopharm, 26:102-103.

Bakalov VK, Cooley MM, Troendle J, Bondy CA(2004): The prevalence of diabetes mellitus in the parents of women with Turner's syndrome. Clin Endocrinol (Oxf) 60:272.

Bayraktar M, Van Thiel DH, Adalar N. A comparison of acarbose versus metformin as an adjuvant therapy in sulfonylureatreated NIDDM patients. Diabetes Care 1996; 19: 252-4.

Bavarva JH, Narasimhacharya AVRL. Antihyperglycemic and hypolipidemic effects of Costus speciosus in alloxan induced diabetic rats. Phytother Res 2008; 22: 620-626.

Barnett A. DPP-4 inhibitors and their potential role in the management of type 2 diabetes. Int J Clin Pract 2006; 60(11): 1454-70.

Beck- Nielsen, H. and Groop, L. C. (1994): J. Clin. Invest, 94, 1714- 1721.

Bell DSH. Beta-cell rejuvenation with thiazolidinediones. Am J Med 2003; 115: 20S-3S.

Bouayed J, Piri K, Rammal H, Dicko A, Desor F, Younos C, Soulimani R. Comparative evaluation of the antioxidant potential of some Iranian medicinal plants. Food Chem 2007; 104 (1): 364-368

Brosky G, Logothetopoulos J (1969): Streptozotocin diabetes in the mouse and guinea pig. Diabetes, 8:606-611.

Cai, YZ, Mei S, Jie X, Luo Q, Corke H. Structureradical scavenging activity relationships of phenolic compounds from traditional Chinese medicinal plants. Life Sci 2006; 78(25): 2872-2888.

Chang CC, Lien YC, Liu KC, Lee SS. Lignans from Phyllanthus urinaria. Phytochem 2003; 63: 825-833.

Elder DA, Kaiser- Roger K, Aylsworth AS and Calikoglu (2001): Type I diabetes mellitus in a patient with chromosome 22q11.2 deletion syndrome. Am J Med Genet, 101 (1): 17- 19.

Fröde TS, Medeiros YS. Animal models to test drugs with potential antidiabetic activity. $J$.
Ethnopharmacol 2008; 115: 173-183.

Finegood DT, McArthur MD, Kojwang D, Thomas MJ, Topp BG, Leonard T, et al., Beta-cell mass dynamics in Zucker diabetic fatty rats: rosiglitazone prevents the rise in net cell death. Diabetes 2001; 50(5): 10219.

Grover JK, Vats V. Shifting paradigm: From conventional to alternative medicines - an introduction on traditional Indian medicines. Asia Pacific Biotech News 2001; 5: 28-32.

Grover JK, Yadav SP. "Pharmacological actions and potential uses of Momordica charantia: A review". J Ethnopharmacol 2004; 93(1): 123-132.

Guerciolini R. Mode of action of orlistat. Int J Obes 1997; 21(suppl 3): S12-S23.

G.B. Kavishankar, N. Lakshmidevi, S. Mahadeva Murthy, H.S. Prakash, S.R. Niranjana (2011): Diabetes and medicinal plants-A review Int J Pharm Biomed Sci 2011, 2(3), 65-80

Hanane Dib, M. Chokri Beghdad and Meriem Belarbi (2013): Phytochemical study of Algerian Opuntia ficus-indica, Annals of Biological Research, 4 (2):185-189

Hatorpe V. Clinical pharmacokinetics and pharmacodynamics of repaglinide. Clin Pharmacokinet 2002; 41: 471-83.

Hanefeld M, Sachse G. The effects of orlistat on body weight and glycaemic control in overweight patients with type 2 diabetes. Diabetes Obes Metab 2002; 4: 415-23.

Herz M, Johns D, Reviriego J, Grossman LD, Godin C, Duran S, et al., A randomized, double-blind, placebo-controlled, clinical trial of the effects of pioglitazone on glycemic control and dyslipidemia in oral antihyperglycemic medication-naive patients with type 2 diabetes mellitus. Clin Ther 2003; 25(4): 1074-95.

Hollander PA, Elbein SC, Hirsch IB, Kelley D, McGill J, Taylor T, et al., Role of orlistat in the treatment of obese patients with type 2 daibetes. Diabetes Care 1998; 21(8):128894.

Holmes BF, Kurth-Kraczek EJ, Winder WW. Chronic activation of 5'-AMP-activated protein kinase increases GLUT-4, hexokinase, and glycogen in muscle. $J$ Appl 
Physiol 1999; 87:1990-5.

Hayashi K, Kojima R, Ito M (2006): Strain differences in the diabetogenic activity of streptozotocin in mice. Biol Pharmaceut Bull, 29:1110-1119.

Heinrich M, Barnes J, Gibbons S, Williamson EM. Fundamentals of Pharmacognocy and Phytotherapy. Churchill Livingston, Elsevier Science Ltd, U.K 2012.

Inzucchi SE. Oral antihyperglycemic therapy for type 2 diabetes. JAMA 2002; 287:360-72.

Iyer, R., Upasani, S. and Baitule, M. N. (2000): ibid, 50, 519, Suppl. 1.

Ikebukuro K, Adachi Y, Yamada Y, Fujimoto S, Seino Y, Oyaizu H (2002): Treatment of Streptozotocin-induced diabetes mellitus by transplantation of islet cells Plus bone Marrow cells via portal vein in rats. Transplantation, 73:512-518.

Ito M (1999): New model of progressive noninsulin-dependent diabetes mellitus in mice induced by Streptozotocin. Biol Pharmaceut Bull, 22:988-989.

Indian Pharmacopoea (2014): Ministry of Health and Family Welfere, Govt. of India

Jada SR, Hamzah AS, Lajis NH, Saad MS, Stevens MF, Stanslas J. Semisynthesis and cytotoxic activities of andrographolide analogues. $J$ Enzyme Inhib Med Chem 2006; 21:145-155.

Kelly IE, Hans TS, Walsh K, Lean ME. Effects of a thiazolidinediones compound on body fat and fat distribution of patients with type 2 diabets. Diabetes Care 1999; 22:288-93.

Kelley DE, Bray GA, Pi-Sunyer FX, Klein S, Hill $\mathrm{J}$, Miles J, et al., Clinical efficacy of orlistat therapy in overweight and obese patients with insulin-treated type 2 diabetes: a 1year randomized controlled trial. Diabetes Care 2002; 25 (6): 1033-41.

Knowler WC, Barrett-Connor E, Fowler SE, Hamman RF, Lachin JM, Walker EA, et al.,; Diabetes Prevention Program Research Grou9. Reduction in the incidence of type 2 diabetes with lifestyle intervention or metformin. $N$ Engl $J$ Med 2002; 346(6):393-403.

Klepzig H, Kober G, Matter C, Luus H, Schneider $\mathrm{H}$, Boedeker $\mathrm{KH}$, et al., Sulfonylureas and ischaemic preconditioning: a double-blind, placebo-controlled evaluation of glimepiride and glibenclamide. Eur Heart $J$ 1999; 20(6): 403-5.

Kirpichnikov D, McFarlane SI, Sowers JR. Metformin: an update. Ann Intern Med 2002; 137:25-33.

Knowler WC, Barrett-Connor E, Fowler SE, Hamman RF, Lachin JM, Walker EA, et al.,; Diabetes Prevention Program Research Grou9. Reduction in the incidence of type 2 diabetes with lifestyle intervention or metformin. $N$ Engl $J$ Med 2002; 346(6):393-403.

Kirpichnikov D, McFarlane SI, Sowers JR. Metformin: an update. Ann Intern Med 2002; 137:25-33.

Klepzig H, Kober G, Matter C, Luus H, Schneider $\mathrm{H}$, Boedeker $\mathrm{KH}$, et al., Sulfonylureas and ischaemic preconditioning: a double-blind, placebo-controlled evaluation of glimepiride and glibenclamide. Eur Heart J 1999; 20(6): 403-5.

Kelly IE, Hans TS, Walsh K, Lean ME. Effects of a thiazolidinediones compound on body fat and fat distribution of patients with type 2 diabets. Diabetes Care 1999; 22:288-93.

King, H., Aubert, R. E. and Herman, W. H. (1998): Diab. Care, 21, 1414- 1431.

Khanna (2001): Int. J. Obesity, 25, 1- 8.

Kelley DE, Bray GA, Pi-Sunyer FX, Klein S, Hill $\mathrm{J}$, Miles J, et al., Clinical efficacy of orlistat therapy in overweight and obese patients with insulin-treated type 2 diabetes: a 1year randomized controlled trial. Diabetes Care 2002; 25 (6): 1033-41.

Lebovitz HE. Alpha-glucosidase inhibitors. Endocrinol Metab Clin North Am 1997; 26: 539-51.

Lebovitz HE. Oral therapies for diabetic hyperglycemia. Endocrinol Metab Clin North Am 2001; 30; 909-33.

Lenzen S. The mechanisms of alloxan- and streptozotocin- induced diabetes. Diabetologia 2008; 51 (2): 216-26.

Lee $\mathrm{CH}$, Olson P, Evans RM. Minireview: lipid metabolism, metabolic diseases, and peroxisome proliferators-activated receptors. Endocrinology 2003; 144: 22012207.

Lin Y, Sun Z. Current views on type 2 diabetes. $J$ Endocrinol 2010; 204: 1-11.

Lister CA, Moore GBT, Piercy V, et al., 
Rosiglitazone, but not metformin or glibenclamide, improves glycaemic control and increases islet insulin content. Diabetologia 1999; 42(suppl 1):A150.

Liu X, Dong M, Chen X, Jiang M, Lv X, Yan G. Antioxidant activity and phenolics of an endophytic Xylaria sp. from Ginkgo biloba. Food Chem 2007; 105(2): 548-554.

Lorke D. A new approach to practical acute toxicity testing. Arch Toxicol 1983; 54: 275-287.

Manisha Modak, Priyanjali Dixit, Jayant Londhe, Saroj Ghaskadbi, and Thomas Paul A. Devasagayam (2007): Indian Herbs and Herbal Drugs Used for the Treatment of Diabetes J Clin Biochem Nutr.; 40(3): 163173.

Mellinger CG, Cipriani TR, Noleto GR, Carbonero ER, Oliveira MB, Gorin PA, Iacomini M. Chemical and immunological modifications of an arabinogalactan present in tea preparations of Phyllanthus niruri after treatment with gastric fluid. Int J Biol Macromol 2008; 43(2): 115-120.

Mellinger C G, Carbonero ER, Cipriani TR, Gorin PA, Iacomini M. Xylans from the medicinal herb Phyllanthus niruri. J Nat Prod 2005a; 68: 129-132.

McLeod JF. Clinical pharmacokinetics of nateglinide. Clin Pharmacokinet 2004; 43:97-120.

McLeod JF. Clinical pharmacokinetics of nateglinide. Clin Pharmacokinet 2004; 43:97-120.

Misra, A., Pandey, R. M., Rama Devi, J., Sharma, R., Vikram, N. K. and Nidhi

Verma, N. P. S. and Madhu, S. V (2000): Diab. Res. Clin. Prac, 50, 615, Suppl. 1.

Mohan, V., Shanthirani, S., Deepa, R., Premalatha, G., Sastry, N. G. and Saroja, R (2001): Diab. Med., 18, 280- 287.

Mohan, V., Shanthirani, S., Deepa, R., Premalatha, G., Sastry, N. G. and Saroja, R (2001): Diab. Med., 18, 280- 287.

Mohler ML, He Y, Wu Z, Dong JH, Miller DD. Recent and emerging anti-diabetes targets. Med Res Rev 2009; 29: 125-195.

Mokhtari D, Myers JW, Welsh N (2008): MAPK kinase kinase-1 is essential for cytokineinduced c-Jun NH2-terminal kinase and nuclear factor- $\kappa \mathrm{B}$ activation in human pancreatic islet cells. Diabetes 57:18961904.

Mushtaq Ahmad, Rahmatullah Qureshi, Muhammad Arshad, Mir Ajab Khan and Muhammad Zafar. 2009. Traditional herbal remedies used for the treatment of diabetes from district attock (Pakistan) Pak. J. Bot., 41(6): 2777-2782, 2009.

Mohler ML, He Y, Wu Z, Dong JH, Miller DD. Recent and emerging anti-diabetes targets. Med Res Rev 2009; 29: 125-195.

Monika Sain, Vandana Sharma (2013): Catharanthus roseus (An anti-cancerous drug yielding plant) - A Review of Potential Therapeutic Properties, Int. J. Pure App. Biosci. 1 (6): 139-142

M.Upendra Rao, M.Sreenivasulu, B.Chengaiah, K.Jaganmohan Reddy, C.Madhusudhana Chetty (2010): Herbal Medicines for Diabetes Mellitus: A Review. International Journal of PharmTech ResearchVol.2, No.3, pp 1883-1892

Neve B, Fernandez-Zapico ME, AshkenaziKatalan V, Dina C, Hamid YH, Joly E, Vaillant E, Benmezroua Y, Durand E, Bakaher N, Delannoy V, Vaxillaire M, Cook T, Dallinga-Thie GM, Jansen $\mathrm{H}$, Charles MA, Clément K, Galan P, Hercberg S, Helbecque N, Charpentier G, Prentki M, Hansen T, Pedersen O, Urrutia R, Melloul $\mathrm{D}$, Froguel P (2005): Role of transcription factor KLF11 and its diabetes-associated gene variants in pancreatic $\beta$ cell function. Proc Natl Acad Sci USA 102:4807-4812

Nesto RW, Bell D, Bonow RO, Fonseca V, Grundy SM, Horton ES, et al., American Heart Association; American Diabetes Association. Thiazolidinedione use, fluid retention, and congestive heart failure: a consensus statement from the American Heart Association and American Diabetes Association. Circulation 2003; 108(23):2941-8.

Nyenwe EA, Jerkins TW, Umpierrez GE, Kitabchi AE. Management of type 2 diabetes: evolving strategies for the treatment of patients with type 2 diabetes. Metabolism 2011; 60:1-23.

Okoli CO, Ibiam AF, Ezike AC, Akah PA, Okoye TC. Evaluation of antidiabetic potentials of Phyllanthus niruri in alloxan diabetic rats. 
Afr J Biotechnol 2010; 9(2): 248-259.

Pallab Das Gupta and Amartya De (2012): Diabetes Mellitus and its Herbal Treatment International Journal of Research in Pharmaceutical and Biomedical SciencesVol. 3 (2), 706- 721.

Palasuwan A, Soogarun S, Lertlum T, Pradniwat P, Wiwanitkit V. Inhibition of Heinz body induction in an in vitro model and total antioxidant activity of medicinal Thai plants. Asian Pac J Cancer Prev 2005; 6: 458-463.

Rakesh Kumar Singh, Dolly Jaiswal, Prashant Kumar Rai, (2009): Anti-diabetic activity of Emblica officinalis in animal models.

Raman Kutty, Soman, C. Rt., Joseph, A., Pisharody, R. and Vijayakumar, K. (2000): Natl. Med. J. India, 13, 287- 292.

Ramachandran A, C. Snehalata and Vijay Viswanathan (2002): Burden of type 2 diabetes and its complications- The Indian scenario, CURRENT SCIENCE, 83(12), 1471- 1476.

Reaven, G. M. (1988): Role of insulin resistance in human disease. Diabetes, 37, 15951607.

Rebecca J Gardner, Andrew J Mungall, Ian Dunham, John C K Barber, Julian P H Shield, I Karen Temple, David O Robinson (1999): Localization of a gene for transient neonatal diabetes mellitus to an 18.72 cR3000 ( $\square 5.4 \mathrm{Mb})$ interval on chromosome 6q, J Med Genet;36:192-196.

Raphael KR, Sabu MC. Antidiabetic activity of Phyllanthus niruri, Amala research bulletin 2000; 20: 19-25.

Sharma H, Chandola HM. Prameha in Ayurveda: correlation with obesity, metabolic syndrome, and diabetes mellitus. Part 2-management of Prameha. J Altern Complement Med 2011; 17(7):589-99.

Shimizu S, Ugi S, Maegawa H, Egawa K, Nishio Y, Yoshizaki T, Shi K, Nagai Y, Morino K, Nemoto K. Protein-tyrosine phosphatase I $\mathrm{B}$ as new activator for hepatic lipogenesis via sterol regulatory element-binding protein-1 gene expression. J Biol Chem 2003; 278: 430-95.

Strom BL, Schinnar R, Apter AJ, Margolis DJ, Lautenbach E, Hennessy S, et al., Absence of cross-reactivity between sulfonamide antibiotics and sulfonamide nonantibiotics. N Engl J Med 2003; 349(17): 1628-35.

Salpeter S, Greyber E, Pasternak G, Salpeter E. Risk of fatal and nonfatal lactic acidosis with metformin use in type 2 diabetes mellitus. [Cochrane review]. In: The Cochrane Library; Issue 4, 2004. Oxford: Update Software

Santwana Rani and Baidyanath Kumar (2015): Glycemic control efficacy of Phyllanthus niruri. Linn extract in Diabetic Mice model Int.J.Curr.Microbiol.App.Sci, 4(4): 599-609

Sharma H, Chandola HM. Prameha in Ayurveda: correlation with obesity, metabolic syndrome, and diabetes mellitus. Part 2-management of Prameha. $J$ Altern Complement Med 2011; 17(7):589-99.

Salpeter S, Greyber E, Pasternak G, Salpeter E. Risk of fatal and nonfatal lactic acidosis with metformin use in type 2 diabetes mellitus. [Cochrane review]. In: The Cochrane Library; Issue 4, 2004. Oxford: Update Software

Shukla R., Sharma S. B., Buri D., Probhu K. M.(2000): Medicinal plants for the treatment of Diabetes Mellitus, Indian $J$ Clin Biochem, 15 P: 169

Salgin B, Amin R, Yuen K, Williams RM, Murgatroyd P, Dunger DB (2006): Insulin resistance is an intrinsic defect independent of fat mass in women with Turner's syndrome. Horm Res 65:69-75.

Song B, Scheuner D, Ron D, Pennathur S, Kaufman RJ (2008): Chop deletion reduces oxidative stress, improves $\beta$ cell function, and promotes cell survival in multiple mouse models of diabetes. J Clin Invest 118:3378-3389

Senée V, Chelala C, Duchatelet S, Feng D, Blanc $\mathrm{H}$, Cossec JC, Charon C, Nicolino $M$, Boileau $\mathrm{P}$, Cavener DR, Bougnères $\mathrm{P}$, Taha D, Julier C (2006): Mutations in GLIS3 are responsible for a rare syndrome with neonatal diabetes mellitus and congenital hypothyroidism. Nat Genet 38:682-687.

Strom BL, Schinnar R, Apter AJ, Margolis DJ, Lautenbach E, Hennessy S, et al., Absence of cross-reactivity between sulfonamide antibiotics and sulfonamide nonantibiotics. N Engl J Med 2003; 349(17): 1628-35.

Smith SB, Prior RL, Mersmann HJ (1983): 
Interrelationship between insulin and lipid metabolism in normal and alloxan-diabetic cattle. J Nutr, 113:1002-1015.

Suheir Assady (2009): Challenges and Prospects for Stem Cell-Based Therapy in Diabetes Mellitus israel medical association world fellowship conference VOL 11, 2009.

Suresh Kumar, Rajeshwar Singh, Neeru Vasudeva and Sunil Sharma (2012): Acute and chronic animal models for the evaluation of anti-diabetic agents, Cardiovascular Diabetology 2, 11:9

Szkudelski T (2001): The mechanism of alloxan and streptozotocin action in B cells of the rat pancreas. Physiol Res, 50:537-46.

Takeshita F, Kodama M, Yamamoto H, Ikarashi $\mathrm{Y}$, Ueda $\mathrm{S}$, Teratani $\mathrm{T}$, Yamamoto $\mathrm{Y}$, Tamatani T, Kanegasaki S, Ochiya T, Quinn G (2006): Streptozotocin induced partial beta cell depletion in nude mice without hyperglycaemia induces pancreatic morphogenesis in transplanted embryonic stem cells. Diabetologia, 49:2948-58.

Torben Hansen (2002): Genetics of Type 2 diabetes, CURRENT SCIENCE, 83(12), 1477- 1482.

Tuomilehto J, Lindstrom J, Eriksson JG, Valle TT, Hamalainen $\mathrm{H}$, Ilanne-Parikka $\mathrm{P}$, et al.,; Finnish Diabetes Prevention Study Group. Prevention of type 2 diabetes mellitus by changes in lifestyle among subjects with impaired glucose tolerance. $N$ Engl J Med 2001; 344(18):1343-50.

Tuomilehto J, Lindstrom J, Eriksson JG, Valle TT, Hamalainen H, Ilanne-Parikka $\mathrm{P}$, et al.,; Finnish Diabetes Prevention Study Group. Prevention of type 2 diabetes mellitus by changes in lifestyle among subjects with impaired glucose tolerance. $N$ Engl J Med 2001; 344(18):1343-50.

The Indian Pharmacopoeia, 2012. http://ipc.nic.in

Vladimir K. Bakalov, Clara Cheng, Jian Zhou and Carolyn (2009): X-Chromosome Gene Dosage and the Risk of Diabetes in Turner Syndrome J Clin Endocrinol Metab.; 94(9): 3289-3296

World Health Organization. Diabetes Fact Sheet Number 312 2006; www.who.org.

Wadkar K.A., Magdum C.S., Patil S.S.(2008): "Antidiabetic Potential and Indian Medicinal plants- A Review Article", Journal of Herbal Medicine

Zhao L, Guo M, Matsuoka TA, Hagman DK, Parazzoli SD, Poitout V, Stein R (2005): The islet $\beta$ cell-enriched MafA activator is a key regulator of insulin gene transcription. J Biol Chem 280:11887-11894.

Zhou G, Myers R, Li Y, Chen Y, Shen X, FenykMelody $\mathrm{J}$, et al., Role of AMP-activated protein kinase in mechanism of metformin action. J Clin Invest 2001; 108(8):1167-74.

Zhijun Song, Helle Krogh Johansen, Viggo Faber, Claus Moser, Arsalan Kharazmi, Jorgen Rygaard, And Niels Hoiby (1997): Ginseng Treatment Reduces Bacterial Load and Lung Pathology in Chronic Pseudomonas aeruginosa Pneumonia in Rats, Antimicrobial Agents and Chemotherapy, 41 (5), 961- 964.

Zimmet, P. Z. (1999): Diabetes epidemiology as a tool to trigger diabetes research and care. Diabetologia, 42, 499- 518.

\section{How to cite this article:}

Shilpi Jaya and Baidyanath Kumar. 2017. Hypoglycemic Efficacy of Catharanthus roseus and Opuntia ficusindica in Mice Diabetic Model. Int.J.Curr.Microbiol.App.Sci. 6(7): 1193-1209. doi: https://doi.org/10.20546/ijcmas.2017.607.145 